\section{WUSCHEL induces shoot stem cell activity and developmental plasticity in the root meristem}

\author{
Jean-Luc Gallois, ${ }^{1}$ Fabiana R. Nora, ${ }^{1}$ \\ Yukiko Mizukami, ${ }^{2}$ and Robert Sablowski ${ }^{1,3}$
}

${ }^{1}$ Deptartment of Cell and Developmental Biology, John Innes Centre, Norwich NR4 7UH, United Kingdom; ${ }^{2}$ Plant \& Microbial Biology, University of California, Berkeley, California 94720, USA

Most of the plant shoot originates from a small group of stem cells, which in Arabidopsis are specified by WUSCHEL (WUS). It is unknown whether these cells have an intrinsic potential to generate shoot tissues, or whether differentiation is guided by signals from more mature tissues. Here we show that WUS expression in the root induced shoot stem cell identity and leaf development (without additional cues), floral development (together with LEAFY), or embryogenesis (in response to increased auxin). Thus, WUS establishes stem cells with intrinsic shoot identity and responsive to developmental inputs that normally do not change root identity.

Supplemental material is available at http://www.genesdev. org.

Received November 7, 2003; revised version accepted January 2, 2004.

Plants generate new organs and tissues reiteratively at the meristems, which are groups of undifferentiated, actively dividing cells present in the growing apices and in axillary buds (Weigel and Jürgens 2002). Within the shoot apical meristem (SAM), a small group of centrally located, slowly dividing stem cells is the ultimate source of all meristem cells and therefore all new shoot organs (Stewart and Dermen 1970). In the SAM, stem cells reside in the meristem central zone (CZ), which regularly provides new cells to replenish the peripheral zone (PZ), where new organs are initiated (Gross-Hardt and Laux 2003).

In Arabidopsis, maintenance of the stem cells in the CZ requires WUSCHEL (WUS), which encodes a homeodomain protein (Laux et al. 1996; Mayer et al. 1998). In strong wus mutants, SAM development during embryogenesis is defective, with the CZ occupied by cells that are larger and more vacuolated than the normal meristem cells. When the seedling germinates, one or two leaf primordia emerge at the shoot apex, indicating that $\mathrm{PZ}$ activity is present, but the pool of undifferentiated

[Keywords: Arabidopsis; WUSCHEL; auxin; LEAFY; pluripotency; embryogenesis]

${ }^{3}$ Corresponding author.

E-MAIL robert.sablowski@bbsrc.ac.uk; FAX 44-1603-450045.

Article and publication are at http://www.genesdev.org/cgi/doi/10.1101/ gad.291204. cells is not replenished and organogenesis stops. New leaves are eventually initiated, presumably by a process related to the establishment of axillary meristems, but organogenesis again terminates prematurely. Some mutant plants finally form flowers that lack the innermost organs (stamens and carpels), showing that WUS is also required to sustain organogenesis in the floral meristem.

WUS is first expressed in the 16-cell embryo, preceding meristem development, within the region that originates the embryonic shoot (Mayer et al. 1998). Although no clear function has been attributed to this early expression, ectopic WUS expression induced somatic embryogenesis, suggesting that WUS promotes embryonic identity (Zuo et al. 2002). Subsequent expression of WUS in the vegetative and reproductive meristems is confined to a small group of cells below the CZ. Because of its expression beneath the SAM stem cells, it has been proposed that WUS acts through an intercellular signal that maintains the stem cells (Mayer et al. 1998), but the signal has not yet been identified. The maintenance of stem cells by signals from specialized cells is also seen in the root meristem, and is in fact a common feature of stem cells in plants and animals (Spradling et al. 2001; Weigel and Jürgens 2002; Laux 2003; Sabatini et al. 2003).

One general question in stem cell biology is the extent to which stem cells can be directed to alternative fates by signals from surrounding tissues (transdifferentiation), or whether they have an intrinsically limited range of fates (Weissman et al. 2001). In plants, laser ablation experiments and genetic evidence suggest that the differentiation of meristem cells can be directed by signals from more mature tissues (van den Berg et al. 1995; Stuurman et al. 2002). Thus WUS could act by establishing naïve cells that subsequently differentiate as shoot cell types in response to signals from surrounding shoot tissues. If WUS protects stem cell identity by antagonizing differentiation signals that emanate from surrounding tissues, the question arises whether this antagonism is specialized for signals that promote shoot cell fates, or whether WUS could have a general role in blocking differentiation. Alternatively, WUS could establish stem cells that give rise to shoot tissues, regardless of the differentiating cells surrounding them. To address these questions, we studied the effects of ectopic expression of WUS outside shoots.

\section{Results and Discussion}

To be able to induce the non-cell-autonomous effects of WUS (Mayer et al. 1998), we expressed WUS in roots using a Cre-loxP-based mosaic expression system (Gallois et al. 2002). The plants contained heat shock-inducible Cre recombinase, which catalyzed excision of a $\beta$-glucuronidase (GUS) reporter gene to activate WUS expression from the widely expressed $35 S$ promoter (for simplicity, this genotype will be called "WUSMOS").

RT-PCR confirmed that WUS expression was activated by heat shock in WUSMOS roots, whereas WUS mRNA was undetectable in non-heat-shocked controls (Fig. 1A) or heat-shocked roots that lacked the WUSMOS construct (data not shown). RNA in situ hybridization confirmed that WUS was activated in a mosaic pattern near the root tips (Fig. 1B,C); GUS staining revealed a 


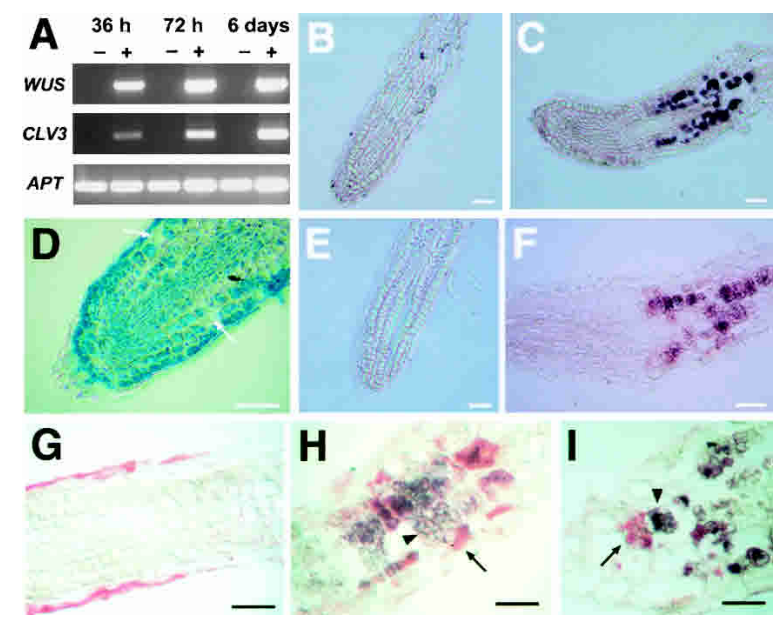

Figure 1. Ectopic WUS activated a shoot stem cell marker in roots. (A) RT-PCR detection of WUS, CLV3, and APT (constitutive control) mRNAs in roots from WUSMOS seedlings at different times after heat shock $(+)$ or in non-heat-shocked controls $(-)$. $(B, C)$ RNA in situ hybridization on longitudinal sections of WUSMOS root tips, $3 \mathrm{~d}$ after heat shock $(C)$ or nonheat-shocked control $(B$; same genotype as in $C)$; the dark signal in $C$ reveals WUS-expressing cells. $(D)$ Longitudinal section of WUSMOS root tips, stained for GUS $3 \mathrm{~d}$ after heat shock; arrows indicate GUS-negative cells. $(E, F)$ As in $B, C$, but hybridized with $C L V 3$ antisense probe. $(G-I)$ Double-labeling RNA in situ hybridization, with WUS signal in red (arrows) and CLV3 signal in blue (arrowheads). (G) Non-heat-shocked control. $(H, I)$ Fixed $3 \mathrm{~d}$ after heat shock. Bar, $40 \mu \mathrm{m}$.

complementary pattern, with scattered GUS-negative cells in the vicinity of the root meristem (Fig. 1D). The lack of WUS-expressing, GUS-negative cells very close to the root tip, $3 \mathrm{~d}$ after heat shock, suggests that either Cre activation was inefficient within the root meristem, or that WUS-expressing cells were left behind as the root tip continued to grow. The region of the root meristem that did not express WUS showed disorganized cell division (Supplemental Material); we do not know whether this was the direct effect of a WUS-induced intercellular signal, or an indirect consequence of the changes in the cells adjacent to the root tip (see following).

In the shoot apex, WUS activates CLAVATA3 (CLV3; Schoof et al. 2000; Brand et al. 2002), which functions in a negative feedback loop that antagonizes WUS activity to control the size of the stem cell population (Fletcher et al. 1999; Brand et al. 2000; Schoof et al. 2000). CLV3 expression specifically marks the shoot stem cells (Laux 2003). We saw that ectopic WUS activated CLV3 in roots, detectable $36 \mathrm{~h}$ after heat shock and maintained for at least $6 \mathrm{~d}$ (Fig. 1A). In situ hybridization showed that the CLV3-expressing cells were present in the same region of the root tip where WUS was activated (Fig. $1 \mathrm{E}, \mathrm{F})$. Double-labeling in situ hybridization, however, revealed that the expression patterns of WUS and CLV3 did not coincide. Separate expression of CLV3 and WUS was seen in adjacent cells (Fig. 1G-I), showing that, as in the shoot apex, WUS expression in the root was able to activate $C L V 3$ non-cell-autonomously.

The $C L V 3$ expression suggested that ectopic WUS was sufficient to induce shoot stem cell identity in the root tips. If the subsequent fate of ectopic shoot stem cells was determined by input from neighboring tissues, the cells should eventually reacquire root identity. Instead, we saw that the WUS- and CLV3-expressing root tip soon developed shoot features. Three to four days after heat shock, the root tips expressed green fluorescent protein (GFP) directed by the promoter from AINTEGUMENTA (ANT, a marker for shoot organ primordia; Elliott et al. 1996; Fig. 2A,B). Activation of endogenous ANT was also confirmed by RT-PCR (data not shown). Six days after heat shock, the root tip contained green tissues (Fig. $2 \mathrm{C}, \mathrm{D}$ ), which either replaced the root tip (Supplemental Material) or were left behind as the tip continued to grow. Between 2 and 3 wk after heat shock, the primary root had developed leaf-like organs in $50 \%$ of the plants $(n=318)$, with characteristic leaf cell types such as guard cells and trichomes (Fig. 2E,F). In other cases (24\%), the root tip formed a green callus containing leaf cell types such as guard cells; in $4 \%$ of the plants, the root tips formed embryo-like structures similar to those described previously (Zuo et al. 2002), whereas the remaining 22\% of the plants had no visible green tissues in the primary root (data not shown). The ectopic leaves formed in heatshocked WUSMOS root tips were made entirely or partially of GUS-positive cells (Fig. 2G,H). As root cells that

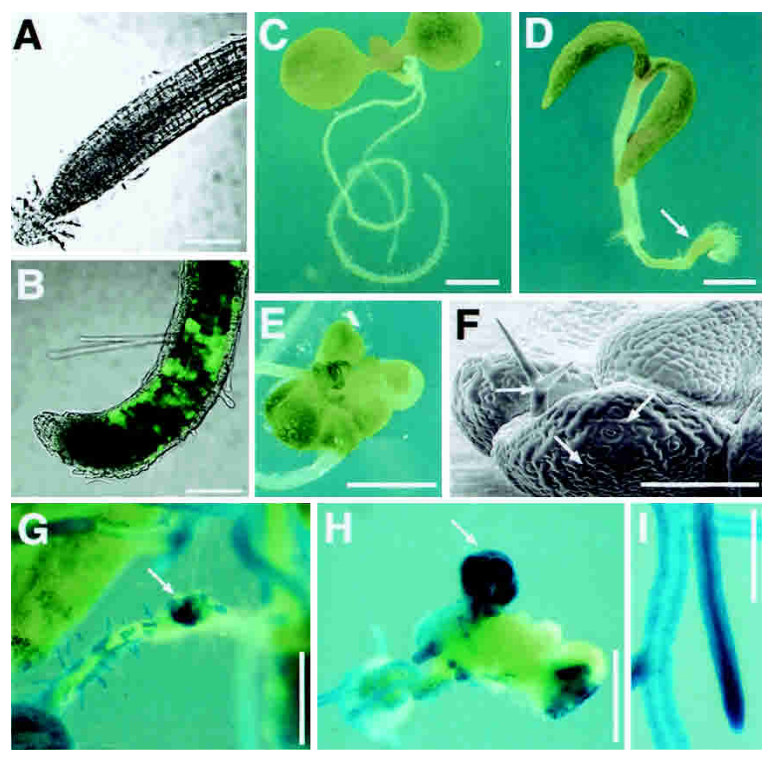

Figure 2. WUS induced the development of shoot tissues from roots. $(A, B)$ Optical sections (combined bright field and GFP channels) of WUSMOS, ANT:GFP root tips. (A) Non-heatshocked control. $(B)$ Four days after heat shock. $(C, D)$ Eight-dayold WUSMOS plants. $(C)$ Non-heat-shocked control. $(D)$ Six days after heat shock, with green tissue near the root tip (arrow). $(E)$ Ectopic leaves on root, $18 \mathrm{~d}$ after heat shock. $(F)$ Electromicrograph of ectopic leaves on WUSMOS root, $21 \mathrm{~d}$ after heat shock; arrows indicate leaf cell types such as interdigitated epidermal cells, guard cells, and a trichome. $(G-I)$ GUS staining of WUSMOS roots of 20-day-old plants, $18 \mathrm{~d}$ after heat shock $(G, H)$ or in non-heat-shocked control $(I)$. $(G)$ Mosaic GUS expression on the primary root and ectopic shoot tissue developing on a lateral root tip (arrow). $(H)$ Ectopic shoot tissue on the primary root tip, $18 \mathrm{~d}$ after heat shock, with a mixture of GUS-positive and GUS-negative tissues; the arrow points at a GUS-positive ectopic leaf. Bars: $A, B, 200 \mu \mathrm{m} ; C-E, 1 \mathrm{~mm} ; F, 100 \mu \mathrm{m} ; G-I$, $500 \mu \mathrm{m}$. 
had not expressed WUS were converted to shoot identity, this response to WUS in the roots was non-cellautonomous. When the roots formed disorganized green tissues, these were made of variable proportions of GUSpositive and GUS-negative cells (Fig. 2G,H; Supplemental Material), suggesting that the WUS-expressing cells also proliferated in WUSMOS root tips.

The induction of ectopic shoot tissues in the roots was confirmed using a gene trap line (J2301), in which genes containing the UAS sequence are activated by GAL4VP16 in the lateral root cap and in the atrichoblasts of the root epidermis (Fig. 3A). Shortly after germination, the root tips of 12301 , UAS:GFP, UAS:WUS seedlings showed aberrant cell divisions both in GFP-negative epidermal cells and in adjacent cells that expressed GFP (and presumably also WUS; Fig. 3B). Subsequently, GFPnegative cells formed outgrowths resembling leaf primordia (Fig. 3D,E), which eventually gave rise to ectopic leaves (Fig. 3F). As in WUSMOS roots, development of ectopic shoot tissues was preceded by $C L V 3$ expression (this time revealed by a CLV3:GUS reporter gene; Brand et al. 2002). Small groups of CLV3:GUS-expressing cells were seen at the root tip shortly after germination (Fig. $3 \mathrm{G}, \mathrm{H})$ and later associated with the ectopic primordia (Fig. 3I), although CLV3:GUS expression eventually dis-
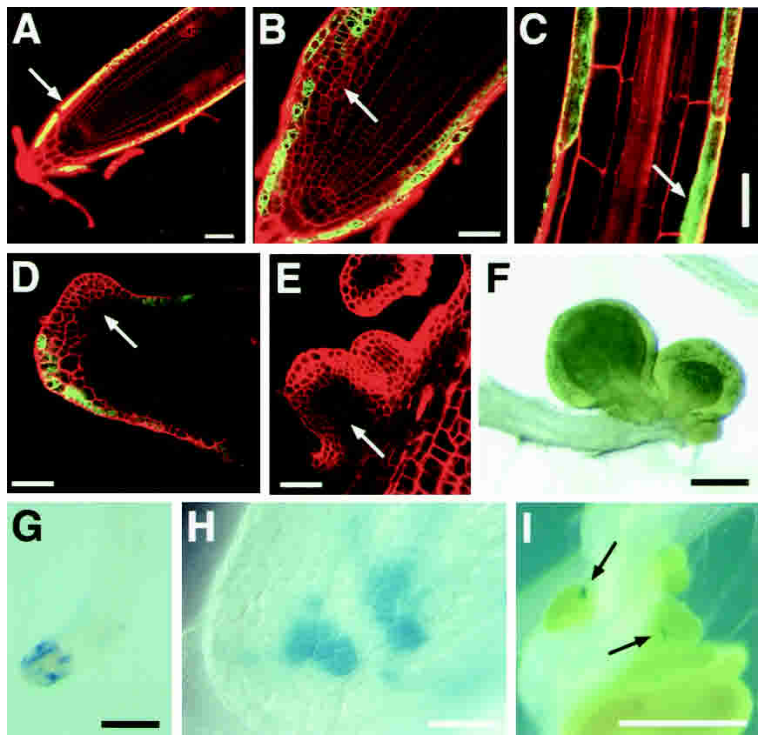

Figure 3. Expression of WUS in the lateral root cap induced ectopic leaf development. $(A-C)$ Optical sections of 72301 roots (GFP and propidium iodide channels combined). (A) J2301, $U A S: G F P$ root tip, $4 \mathrm{~d}$ after germination; the arrow indicates GFP expression in the lateral root cap. (B) J2301, UAS:GFP, $U A S:: W U S$ root tip, $7 \mathrm{~d}$ after germination; the arrow indicates abnormal cell proliferation. (C) Mature section of $J 2301$, UAS:GFP, UAS::WUS root, $7 \mathrm{~d}$ after germination; the arrow indicates GFP expression in atrichoblasts. $(D-E)$ Ectopic leaf primordia (arrows) on secondary root tips of 12301, UAS:GFP, $U A S:: W U S$ plants, $21 \mathrm{~d}$ after germination. $(F)$ Ectopic leaves on the primary root tip of $2301, U A S: G F P, U A S: W U S$ plant, $21 \mathrm{~d}$ after germination. (G-I) GUS staining of 12301, UAS:GFP, UAS:WUS, CLV3:GUS root tips. $(G, H)$ Primary root tip, $7 \mathrm{~d}$ after germination. (I) Secondary root tip, $21 \mathrm{~d}$ after germination; arrows indicate CLV3:GUS expression (blue signal) associated with ectopic leaf primordia. Bars: $A-E, H, 40 \mu \mathrm{m} ; F, G, I, 200 \mu \mathrm{m}$.
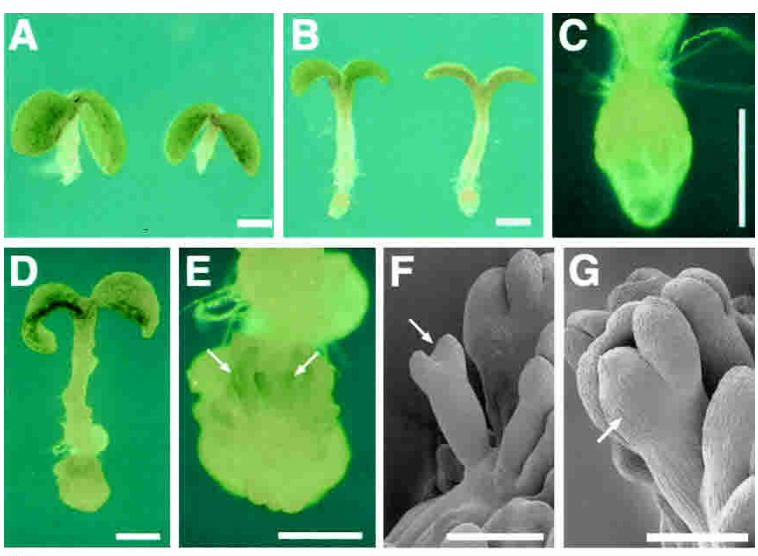

H
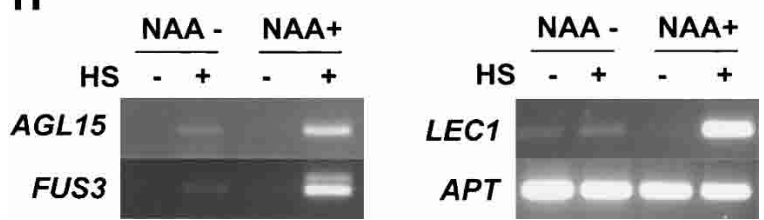

Figure 4. WUS expression combined with auxin induced somatic embryogenesis in roots. $(A-C)$ Eight-day-old WUSMOS seedlings grown on medium with $5 \mu \mathrm{M}$ NAA, without heat shock $(A)$ or $6 \mathrm{~d}$ after heat $\operatorname{shock}(B) ; C$ is a higher-magnification view of the root tip of a seedling equivalent to $B .(D, E)$ Twentyday-old WUSMOS seedling grown with $5 \mu \mathrm{M}$ NAA, $18 \mathrm{~d}$ after heat shock; the root tip of $D$ is shown at higher magnification in $E$, with arrows indicating somatic embryos. $(F, G)$ Cryo-scanning electron micrographs of 2-week-old heat shocked WUSMOS plants grown on medium containing $5 \mu \mathrm{M}$ NAA. Arrows indicate somatic embryos. $(H)$ RT-PCR detection of embryo marker mRNAs and constitutive control (APT) in roots dissected from WUSMOS seedlings, not heat shocked (HS-) or 2 wk after heat shock (HS+), grown in GM medium (NAA-) or medium supplemented with NAA $5 \mu \mathrm{M}(\mathrm{NAA}+)$. Bars: $A-E$, $1 \mathrm{~mm} ; F, G, 100 \mu \mathrm{m}$.

appeared as the leaves grew (data not shown). These results are compatible with the idea that descendants of CLV3-expressing cells formed the ectopic shoot tissues, although definitive proof of this will require clonal analysis.

In both the WUSMOS and in the UAS:WUS experiments, phenotypic effects were only seen in the primary and lateral root tips, despite the fact that heat shockinduced Cre catalyzed GUS excision throughout the roots (Fig. 2G), and that GFP (and presumably WUS) was expressed in the atrichoblasts of more mature root regions (Fig. 3C). As the response to WUS expression in roots was restricted to the meristematic regions, we aimed to expand WUS action, using external application of auxin to induce larger numbers of lateral root meristems (King et al. 1995). Unexpectedly, these experiments showed a change in the fate of the cells responding to WUS. When heat-shocked WUSMOS seedlings were plated on medium containing $5 \mu \mathrm{M}$ of the synthetic auxin $\alpha$-naphtalene acetic acid (NAA), none of the roots formed ectopic leaves, and instead virtually all developed structures resembling embryos, mostly oriented with their shoot poles away from the root tip (Fig. 4). We also noticed that the inhibition of hypocotyl elongation by auxin was somewhat suppressed in seedlings where 
WUS was activated (Fig. 4, cf. A and B); we do not know whether this is an effect of ectopic WUS in the hypocotyl or in the root. Embryonic identity was confirmed by activation of embryo marker genes such as LEC1, FUS3, and AGL15 (Fig. 4H; Heck et al. 1995; Rounsley et al. 1995; Lotan et al. 1998; Luerssen et al. 1998). In the absence of external auxin, heat-shocked WUSMOS roots expressed these embryonic markers at a low level, yet higher than in the roots of non-heat-shocked plants. The low levels of embryonic gene expression in WUSMOS plants without added auxin are consistent with the embryo-like structures that developed on the root tips of these plants at a low frequency and may be due to the endogenous auxin that accumulates at the root tips (Sabatini et al. 1999).

The somatic embryos described earlier are in agreement with the previous report (Zuo et al. 2002) that expression of WUS in roots induced somatic embryogenesis. The effect of auxin is in accordance with the observation that it promotes somatic embryogenesis in tissue culture, is present at high levels in early embryos, and is essential for normal embryo patterning (Feher et al. 2003; Friml et al. 2003). Thus, it appeared that, depending on auxin levels, ectopic WUS could redirect root cells to at least two different developmental pathways: shoot organogenesis or somatic embryogenesis.

To test whether WUSMOS roots could be directed to another of the developmental pathways in which WUS normally functions, we combined WUSMOS with constitutive expression of LEAFY (LFY), which is a master regulator of floral development (Weigel et al. 1992). Expression of LFY using the 35S promoter (35S:LFY) caused early flowering and conversion of the inflorescence meristem to floral meristem (Weigel and Nilsson 1995). 35S:LFY alone, however, does not bypass the vegetative phase (when the shoot meristem produces leaves), does not alter embryogenesis, and has no effect on root development.

Heat shock had no effect on the development of 35S:LFY plants. When 35S:LFY, WUSMOS seedlings were heat shocked, floral organs and tissues developed from primary and lateral root tips (Fig. 5). These organs were not organized in the normal whorled arrangement seen in flowers, and their identity seemed random, with various combinations of sepals (Fig. 5A,E), stamens (Fig. $5 \mathrm{C}$ ), and carpel tissue (such as the stigmatic papillae shown in Fig. 5D,E). We cannot discriminate whether WUS only acted to establish pluripotent cells, with LFY subsequently directing their development, or whether WUS also acted directly in combination with LFY to control genes involved in floral development. The latter possibility is based on the fact that during flower development, the organ identity gene AGAMOUS $(A G)$ is directly activated by WUS combined with LFY (Lenhard et al. 2001; Lohmann et al. 2001). However, an indirect interaction between $L F Y$ and WUS is also evident during normal floral development: $L F Y$ confers floral identity throughout the floral meristem, including cells that do not express WUS, but whose maintenance requires WUS.

Our results showed that WUS expression made root cells developmentally flexible and able to be directed to embryo, leaf, or floral organ development, depending on additional cues. The ability to enter alternative developmental pathways, combined with expression of a stem
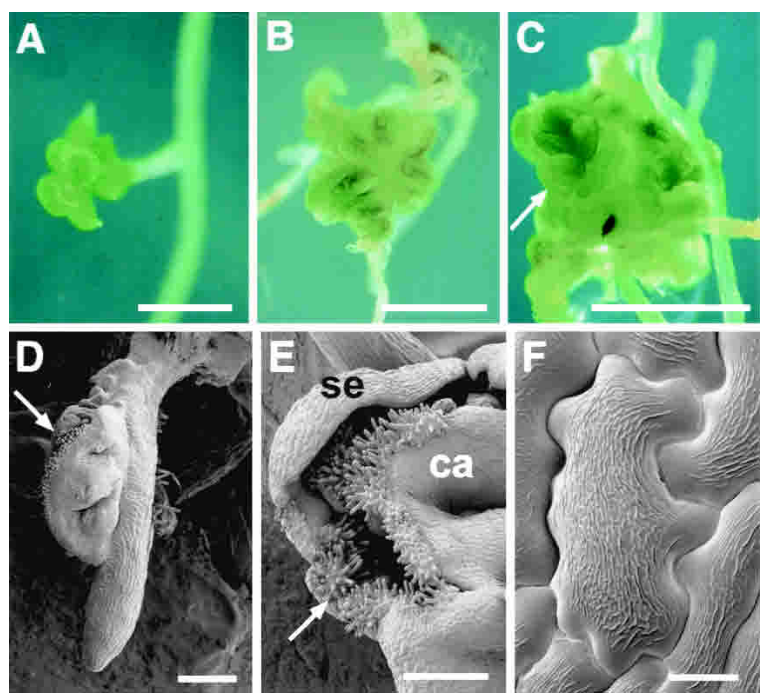

Figure 5. Floral tissues in the roots of 21-day-old WUSMOS, 35S:LFY plants, $19 \mathrm{~d}$ after heat shock. (A) Sepals on lateral root tip. (B) Sepal and carpel-like organs on lateral root tip. (C) Arrow indicates anther originated from lateral root tip. $(D-F)$ Cryoscanning electron micrographs showing carpelloid tissue on primary root tip $(D)$, sepaloid (se) and carpelloid (ca) tissues on lateral root tip, with arrow indicating stigmatic papillae $(E)$, and an epidermal cell with the epicuticular ridges typically seen in floral organs $(F)$. Bars: $A-C, 1 \mathrm{~mm} ; D, E, 200 \mu \mathrm{m} ; F, 10 \mu \mathrm{m}$.

cell marker (CLV3), indicates that expression of WUS in the root caused ectopic activation of stem cell functions. The ectopic organs and embryo-like structures, however, did not maintain a stable pool of stem cells, and their development eventually terminated. This may be due to the fact that maintenance of a stable stem cell population requires feedback regulation of WUS by the CLAVATA pathway (Brand et al. 2000; Schoof et al. 2000), which cannot operate on the heterologous promoters used here (Gallois et al. 2002). Alternatively, other genes required for meristem activity, such as SHOOT MERISTEMLESS (Long et al. 1996), may not have been activated.

It is striking that when WUS was expressed in the roots with no additional cues (i.e., not combined with LFY or external auxin), ectopic leaves developed. Ectopic shoot identity did not occur simply because WUS rendered the root cells responsive to light as a developmental input, because $A N T$ was still activated by WUS in the root tips of seedlings that were heat shocked and grown in the dark (data not shown). Our experiments leave two possibilities open. One is that, unless root identity is actively maintained, shoot development occurs by default. This could reflect the evolutionary origin of roots as an addition to preexisting shoots (Kenrick and Crane 1997). The alternative is that WUS itself provided the cues that converted the cells to shoot identity. Either way, the results imply that WUS does not simply establish naïve cells that require input from surrounding tissues to develop as shoot cells, but instead establishes cells with intrinsic potential to generate shoot tissues. Although we cannot exclude that WUS could induce stem cells and shoot identity through parallel pathways, the most straightforward interpretation of our results is 
that shoot identity is a property of the stem cells specified by WUS.

We also saw that WUS made cells within or in the vicinity of the root meristem responsive to inputs that normally do not redirect root cell identity (e.g., LFY for floral development, increased auxin for embryogenesis). In addition to supporting the proposed role of WUS in promoting pluripotency (Mayer et al. 1998), this developmental plasticity may have practical use. Although plant development is remarkably plastic and virtually all parts of plants can be regenerated in tissue culture from fragments of adult plants, the conditions defined in tissue culture cannot override developmental controls in whole plants. We have shown that a gene that controls stem cell identity can be used to redirect root cells of an intact plant to any of the other major sporophytic developmental pathways-leaf, floral, or embryo development.

\section{Materials and methods}

Arabidopsis lines

hsp18.2:Cre (gift from Leslie Sieburth, Ohio State University), 35S:loxuidA-lox-WUS and 35S:lox-uidA-lox-GFP, and CLV3:GUS have already been described (Sieburth et al. 1998; Brand et al. 2002; Gallois et al. 2002). The gene trap line J2301 (from Jim Haseloff, Cambridge University) was obtained through the Nottingham Arabidopsis Stock Centre (http:// nasc.life.nott.ac.uk). UAS:WUS was constructed with the UAS sequence (HindIII-BamHI, from the same vector used to create the gene trap lines), the WUS cDNA (BamHI-SpeI; Gallois et al. 2002) and the NOS terminator (XbaI-PstI, from pCGN18; Krizek and Meyerowitz 1996) inserted between the SmaI and PstI sites of pPZP222 (Hajdukiewicz et al. 1994). The plasmid was transformed into Arabidopsis thaliana Landesbergerecta (L-er) by the floral dip method (Clough and Bent 1998) and lines were selected that segregated a single UAS:WUS locus (based on gentamycin resistance). GAL4-VP16-directed WUS expression was analyzed in the progeny between homozygous UAS:WUS and gene trap lines, with crosses between L-er and the gene traps as controls. ANT:GFP was generated by inserting a $4.2-\mathrm{kb}$ region upstream of the $A N T$ initiation codon into the HindIII and BamHI sites of mGFP5-ER (Haseloff 1999) and transformed in Arabidopsis thaliana Columbia background. Expression in more than 20 independent lines was essentially as described by Schoof et al. (2000; Y. Mizukami, unpubl.).

For LEAFY (LFY) overexpression, Arabidopsis thaliana Columbia were transformed by the floral dip method with pDW151 (Weigel and Nilsson 1995). Expression of LFY mRNA in the roots of the transformed lines was checked by RT-PCR with primers 5'-GATTCCGGTACTCATCACGC$3^{\prime}$ and 5'-GGCTTGTAACAAGCCTGACGCCA-3'.

\section{Growth conditions}

Seeds were surface-sterilized by chlorine gas by being kept $7 \mathrm{~h}$ in a desiccator with a mixture of $100 \mathrm{~mL}$ commercial bleach and $3 \mathrm{~mL}$ concentrated hydrochloric acid in a fume hood. Sterile seeds were plated on GM medium (Valvekens et al. 1988), stratified for $2 \mathrm{~d}$ at $4^{\circ} \mathrm{C}$, and grown in 16 $\mathrm{h}$ light $/ 8 \mathrm{~h}$ dark cycles (fluorescent lights at $\sim 100$ umole photons $\mathrm{m}^{-2} \mathrm{sec}^{-1}$ ) at $18^{\circ} \mathrm{C}-20^{\circ} \mathrm{C}$. For auxin treatment, GM was supplemented with $5 \mu \mathrm{M}$ NAA solution (Sigma).

Activation of Cre recombinase

Wild-type (L-er) or 35S:LFY plants were emasculated and fertilized $2 \mathrm{~d}$ later with 35S:lox-uidA-lox-WUS; hsp18.2:Cre pollen. For heat shock, seeds were plated on GM medium and sealed plates were incubated for 30 $\min$ at $38^{\circ} \mathrm{C}$.

\section{Microscopy}

mRNA in situ hybridization on tissue sections with digoxigenin (DIG)labeled WUS or CLV3 cDNA was as described (Fobert et al. 1996). Double labeling was as described (Fobert et al. 1996), with the WUS probe labeled with fluorescein, developed with Fast Red TR/Naphthol AS-MX (Sigma) and DIG-labeled CLV3 developed with BCIP/NIBT. For whole-mount GUS detection, tissues were fixed for $10 \mathrm{~min}$ in ice-cold $90 \%$ acetone and stained for GUS as described (Sieburth et al. 1998). For GUS detection in sectioned tissues, roots were first stained for GUS for $90 \mathrm{~min}$ at $30^{\circ} \mathrm{C}$, followed by fixation with and sectioning as for in situ hybridization. For root confocal imaging, cell outlines were marked by staining with $50 \mu \mathrm{M}$ propidium iodide. A Leica TCS SP microscope was used, with excitation set at $488 \mathrm{~nm}$; emission was filtered to 500-550 nm (GFP) or 600-660 nm (propidium iodide), or was not filtered, for bright field. GFP-negative controls gave no signal in the GFP channel with the settings used. For cryo-scanning electron microscopy, seedlings were frozen in nitrogen slush at $-190^{\circ} \mathrm{C}$. Ice was sublimated at $-90^{\circ} \mathrm{C}$; the specimen was sputter coated and examined on a Philips XL 30 FEG SEM fitted with a cold stage. Images were processed (color balance, contrast, cropping, orientation) using Adobe Photoshop 5.0.

RNA extraction and RT-PCR

RNA was extracted using TRI reagent (Sigma). RT-PCR were carried out with Superscript Rnase H- reverse transcriptase (GIBCO-BRL) on $1 \mu \mathrm{g}$ total RNA according to the supplier's instructions. One-twentieth of the RT product was used for each subsequent PCR amplification. Amplification was initiated by adding Taq polymerase at $94^{\circ} \mathrm{C}$, followed by 25-35 cycles of $30 \mathrm{sec}$ at $94^{\circ} \mathrm{C}, 30 \mathrm{sec}$ at $55^{\circ} \mathrm{C}$, and $60 \mathrm{sec}$ at $72^{\circ} \mathrm{C}$. The primers used were as follows: LEC1, 5'-ACCAGCTCAGTCATAG TAGCCG-3' and 5'-CTTATACTGACCATAATGGTCAAA-3'; FUS3, 5'-GAATGCAAGGAAGGGATTCCTA-3' and 5'-CCCAAACCATCGAA TGTTCCGAAC-3' ${ }^{\prime}$; AGL15 , 5' -ATCGAGATAAAGAGGATCGAGA-3' and 5'-GAGAAAGCTCCTCAGTTCTTG-3'; WUS, 5'-AGTCGGATC CAACACACATGGAGCCGCCAC- $3^{\prime}$ and $5^{\prime}$-CGGCTCTAGAGCTAG TTCAGACGTAGCTCA-3'; CLV3, 5' -CTTTGGATCCAAAAATGGAT TCTAAAAGCTTTG- $3^{\prime}$ and 5'-ATAATCTAGAGCAACAAGAGAT TAGGTCAAG-3'. The APT cDNA (Moffatt et al. 1994) was amplified as a control with oligonucleotides 5'-CCTTTCCCTTAAGCTCTG-3' and 5'-TCCCAGAATCGCTAAGATTGCC-3'

\section{Acknowledgments}

We are grateful to the Nottingham Arabidopsis Stock Centre for gene trap line J2301, to Detlef Weigel for pDW151, to Rüdiger Simon for CLV3:GUS seeds, and to Des Bradley and Nick Harberd for critical comments. This work was funded by grants from the European Union (QLG2CT-199900876) and BBSRC (208/G17506). F.N. was funded by a fellowship from CNPq.

The publication costs of this article were defrayed in part by payment of page charges. This article must therefore be hereby marked "advertisement" in accordance with 18 USC section 1734 solely to indicate this fact.

\section{References}

Brand, U., Fletcher, J.C., Hobe, M., Meyerowitz, E.M., and Simon, R. 2000. Dependence of stem cell fate in Arabidopsis on a feedback loop regulated by CLV3 activity. Science 289: 617-619.

Brand, U., Grunewald, M., Hobe, M., and Simon, R. 2002. Regulation of CLV3 expression by two homeobox genes in Arabidopsis. Plant Physiol. 129: 565-575.

Clough, S.J. and Bent, A.F. 1998. Floral dip: A simplified method for Agrobacterium-mediated transformation of Arabidopsis thaliana. Plant J. 16: 735-743.

Elliott, R.C., Betzner, A.S., Huttner, E., Oakes, M.P., Tucker, W.Q.J. Gerentes, D., Perez, P., and Smyth, D.R. 1996. AINTEGUMENTA, an APETALA2-like gene of Arabidopsis with pleiotropic roles in ovule development and floral organ growth. Plant Cell 8: 155-168.

Feher, A., Pasternak, T.P., and Dudits, D. 2003. Transition of somatic plant cells to an embryogenic state. Plant Cell Tissue Organ Cult. 74: 201-228.

Fletcher, J.C., Brand, U., Running, M.P., Simon, R., and Meyerowitz, E.M. 1999. Signaling of cell fate decisions by CLAVATA3 in Arabidopsis shoot meristems. Science 283: 1911-1914.

Fobert, P.R., Gaudin, V., Lunness, P., Coen, E.S., and Doonan, J.H. 1996 Distinct classes of cdc2-related genes are differentially expressed during the cell division cycle in plants. Plant Cell 8: 1465-1476.

Friml, J., Vieten, A., Sauer, M., Weijers, D., Schwarz, H., Hamann, T., 


\section{Gallois et al.}

Offringa, R., and Jürgens, G. 2003. Efflux-dependent auxin gradients establish the apical-basal axis of Arabidopsis. Nature 426: 147153.

Gallois, J.L., Woodward, C., Reddy, G.V., and Sablowski, R. 2002. Combined SHOOT MERISTEMLESS and WUSCHEL trigger ectopic organogenesis in Arabidopsis. Development 129: 3207-3217.

Gross-Hardt, R. and Laux, T. 2003. Stem cell regulation in the shoot meristem. J. Cell Sci. 116: 1659-1666.

Hajdukiewicz, P., Svab, Z., and Maliga, P. 1994. The small, versatile pPZP family of Agrobacterium binary vectors for plant transformation. Plant Mol. Biol. 25: 989-994.

Haseloff, J. 1999. GFP variants for multispectral imaging of living cells. Methods Cell Biol. 58: 139-151.

Heck, G.R., Perry, S.E., Nichols, K.W., and Fernandez, D.E. 1995. AGL15, a MADS domain protein expressed in developing embryos. Plant Cell 7: 1271-1282.

Kenrick, P. and Crane, P.R. 1997. The origin and early diversification of land plants-A cladistic study. Smithsonian Institution Press, Washington, D.C.

King, J.J., Stimart, D.P., Fisher, R.H., and Bleecker, A.B. 1995. A mutation altering auxin homeostasis and plant morphology in Arabidopsis. Plant Cell 7: 2023-2037.

Krizek, B.A. and Meyerowitz, E.M. 1996. The Arabidopsis homeotic genes APETALA3 and PISTILLATA are sufficient to provide the B class organ identity function. Development 122: 11-22.

Laux, T. 2003. The stem cell concept in plants: A matter of debate. Cell 113: $281-283$.

Laux, T., Mayer, K.F., Berger, J., and Jürgens, G. 1996. The WUSCHEL gene is required for shoot and floral meristem integrity in Arabidopsis. Development 122: 87-96.

Lenhard, M., Bohnert, A., Jürgens, G., and Laux, T. 2001. Termination of stem cell maintenance in Arabidopsis floral meristems by interactions between WUSCHEL and AGAMOUS. Cell 105: 805-814.

Lohmann, J.U., Hong, R.L., Hobe, M., Busch, M.A., Parcy, F., Simon, R., and Weigel, D. 2001. A molecular link between stem cell regulation and floral patterning in Arabidopsis. Cell 105: 793-803.

Long, J.A., Moan, E.I., Medford, J.I., and Barton, M.K. 1996. A member of the KNOTTED class of homeodomain proteins encoded by the STM gene of Arabidopsis. Nature 379: 66-69.

Lotan, T., Ohto, M., Yee, K.M., West, M.A., Lo, R., Kwong, R.W., Yamagishi, K., Fischer, R.L., Goldberg, R.B., and Harada, J.J. 1998. Arabidopsis LEAFY COTYLEDON1 is sufficient to induce embryo development in vegetative cells. Cell 93: 1195-1205.

Luerssen, H., Kirik, V., Herrmann, P., and Misera, S. 1998. FUSCA3 encodes a protein with a conserved VP1/AB13-like B3 domain which is of functional importance for the regulation of seed maturation in Arabidopsis thaliana. Plant J. 15: 755-764.

Mayer, K.F., Schoof, H., Haecker, A., Lenhard, M., Jürgens, G., and Laux, T. 1998. Role of WUSCHEL in regulating stem cell fate in the Arabidopsis shoot meristem. Cell 95: 805-815.

Moffatt, B.A., McWhinnie, E.A., Agarwal, S.K., and Schaff, D.A. 1994. The adenine phosphoribosyltransferase-encoding gene of Arabidopsis thaliana. Gene 143: 211-216.

Rounsley, S.D., Ditta, G.S., and Yanofsky, M.F. 1995. Diverse roles for MADS box genes in Arabidopsis development. Plant Cell 7: 12591269.

Sabatini, S., Beis, D., Wolkenfelt, H., Murfett, J., Guilfoyle, T., Malamy, J., Benfey, P., Leyser, O., Bechtold, N., Weisbeek, P., et al. 1999. An auxin-dependent distal organizer of pattern and polarity in the Arabidopsis root. Cell 99: 463-472.

Sabatini, S., Heidstra, R., Wildwater, M., and Scheres, B. 2003. SCARECROW is involved in positioning the stem cell niche in the Arabidopsis root meristem. Genes \& Dev. 17: 354-358.

Schoof, H., Lenhard, M., Haecker, A., Mayer, K.F.X., Jürgens, G., and Laux, T. 2000. The stem cell population of Arabidopsis shoot meristems is maintained by a regulatory loop between the CLAVATA and WUSCHEL genes. Cell 100: 635-644.

Sieburth, L.E., Drews, G.N., and Meyerowitz, E.M. 1998. Non-autonomy of AGAMOUS function in flower development: Use of a Cre/loxP method for mosaic analysis in Arabidopsis. Development 125: 43034312.

Spradling, A., Drummond-Barbosa, D., and Kai, T. 2001. Stem cells find their niche. Nature 414: 98-104.
Stewart, R.N. and Dermen, H. 1970. Determination of number and mitotic activity of shoot apical initial cells by analysis of mericlinal chimeras. Am. J. Bot. 57: 816-826.

Stuurman, J., Jaggi, F., and Kuhlemeier, C. 2002. Shoot meristem maintenance is controlled by a GRAS-gene mediated signal from differentiating cells. Genes \& Dev. 16: 2213-2218.

Valvekens, D., Vanmontagu, M., and Vanlijsebettens, M. 1988. Agrobacterium-tumefaciens-mediated transformation of Arabidopsisthaliana root explants by using kanamycin selection. Proc. Natl. Acad. Sci. 85: 5536-5540.

van den Berg, C., Willemsen, V., Hage, W., Weisbeek, P., and Scheres, B. 1995. Cell fate in the Arabidopsis root meristem determined by directional signalling. Nature 378: 62-65.

Weigel, D. and Jürgens, G. 2002. Stem cells that make stems. Nature 415: 751-754.

Weigel, D. and Nilsson, O. 1995. A developmental switch sufficient for flower initiation in diverse plants. Nature 377: 495-500.

Weigel, D., Alvarez, J., Smyth, D.R., Yanofsky, M.F., and Meyerowitz, E.M. 1992. LEAFY controls floral meristem identity in Arabidopsis. Cell 69: 843-859.

Weissman, I.L., Anderson, D.J., and Gage, F. 2001. Stem and progenitor cells: Origins, phenotypes, lineage commitments, and transdifferentiations. Annu. Rev. Cell Dev. Biol. 17: 387-403.

Zuo, J., Niu, Q.W., Frugis, G., and Chua, N.H. 2002. The WUSCHEL gene promotes vegetative-to-embryonic transition in Arabidopsis. Plant $\mathrm{T}$. 30: $349-359$. 


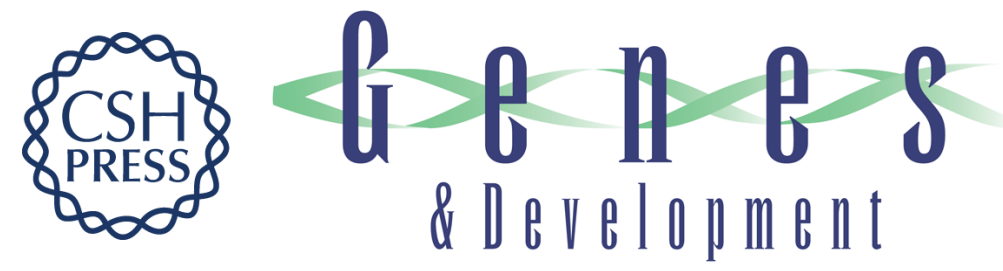

\section{WUSCHEL induces shoot stem cell activity and developmental plasticity in the root meristem}

Jean-Luc Gallois, Fabiana R. Nora, Yukiko Mizukami, et al.

Genes Dev. 2004, 18:

Access the most recent version at doi:10.1101/gad.291204

\section{Supplemental http://genesdev.cshlp.org/content/suppl/2004/02/13/18.4.375.DC1 Material}

References This article cites 38 articles, 16 of which can be accessed free at: http://genesdev.cshlp.org/content/18/4/375.full.html\#ref-list-1

\section{License}

Email Alerting

Receive free email alerts when new articles cite this article - sign up in the box at the top Service

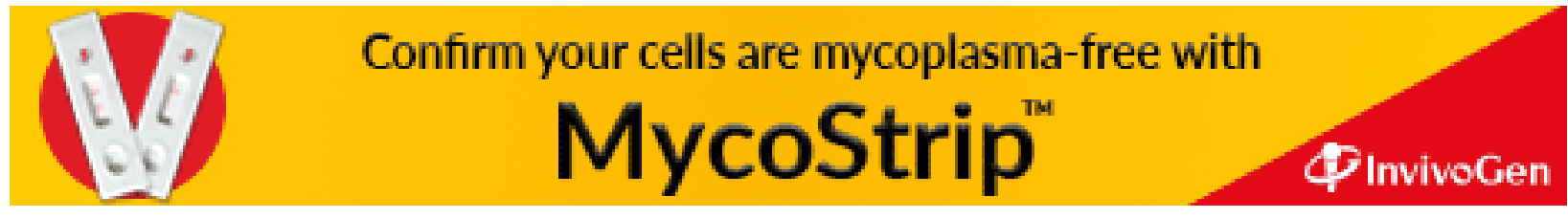

